\title{
JERZY ADAMSKI I JEGO NIEZNANY PRZEKŁAD DOM JUANA MOLIERA
}

DOI: http://dx.doi.org/10.12775/RP.2017.017

\begin{abstract}
Zarys treści: Jerzy Adamski (1922-2001) - wybitny literaturoznawca i pedagog, autor wielu szkiców i esejów, był także tłumaczem włoskich i francuskich dramatów. Przekłady te inscenizowano w wielu polskich teatrach. Jest on także autorem nigdy nie wystawionego w teatrze Molierowskiego Dom Juana. Przekład ten pochodzi z 1990 roku i istnieje tylko w formie maszynopisu z odręcznymi poprawkami tłumacza. Celem niniejszego tekstu jest przybliżenie tego przekładu szerszej publiczności oraz próba jego analizy i porównania z powstałym w tym samym dziesięcioleciu tłumaczeniem dramatu autorstwa Jerzego Radziwiłowicza (1996).
\end{abstract}

Słowa kluczowe: Adamski, przekład teatralny, ślady łłumacza, Berman, tłumaczenie literalne

Wi edług francuskiego tłumacza i przekładoznawcy Antoine’a Bermana, zwolennika tzw. „pozytywnej krytyki przekładu” analizie tłumaczenia powinno towarzyszyć pytanie, kim jest tłumacz. „Ważne jest dla nas - pisał - by wiedzieć, czy jest on Francuzem czy obcokrajowcem, czy jest «tylko» tłumaczem lub czy wykonuje jakiś inny znaczący zawód [...]; chcemy wiedzieć, czy jest także autorem i napisał jakieś dzieła [...], jakiego typu dzieła zwykle tłumaczy i jakie inne utwory przełożył; [...] chcemy wiedzieć, jakie są jego językowe i literackie kompetencje; [...] czy pisał artykuły, rozprawy, książki poświęcone dziełom, które przełożył, i wreszcie czy pisał o swojej praktyce tłumacza, o zasadach, jakimi się kieruje, o swoich tłumaczeniach i o tłumaczeniu w ogóle” (Berman 1995: 74). Informacje te należy - uważa Berman - uzupełnić, definiując pozycję, projekt oraz horyzont tłumacza. „Każdego tłumacza charakteryzuje bowiem jego specyficzny stosunek do własnej aktywności: ma 
on zwykle jakąś koncepcję, spojrzenie na przekład, jego sens, cele, formy i style. To spojrzenie nie ma charakteru czysto osobistego, każdy bowiem tłumacz naznaczony jest przez liczne uwarunkowania natury historycznej, społecznej czy literackiej, także przez ideologiczne spojrzenie zarówno na pracę przekładową, jak i twórczość literacką. Pozycja tłumacza jest więc rodzajem kompromisu między sposobem, w jaki postrzega on swoją pracę, a sposobem, w jaki przyswoił sobie pewne istniejące normy tłumaczenia" (Niziołek 2014: 43-44). „Projekt zdeterminowany jest $\mathrm{z}$ jednej strony pozycją tłumaczeniową, $\mathrm{z}$ drugiej zaś wymogami (za każdym razem specyficznymi), jakie narzuca dzieło, które mamy przetłumaczyć. Określa on zarówno sposób, w jaki tłumacz dokonać zamierza translacji literackiej, jak i wybór metody tłumaczenia" (Niziołek 2014: 43-44)1. Berman podkreśla, że tak zdefiniowany projekt nie jest $\mathrm{w}$ żadnej mierze projektem teoretycznym czy jakimś schematem a priori; można go bowiem odczytać wyłącznie poprzez ukończony już przekład dzieła. Zarówno pozycja, jak i projekt tłumacza sytuują się - zdaniem Bermana - w pewnym horyzoncie hermeneutycznym, który możemy zdefiniować jako „ogół parametrów językowych, literackich, kulturowych i historycznych, które determinują sposób odczuwania, myślenia, działania tłumacza" (Niziołek 2014: 5). Powróćmy zatem do pytania, kim jest tłumacz.

We wstępie do wydanego w roku 1985 pamiętnika teatralnego $\mathrm{z}$ lat 1971-1981, zatytułowanego Teatr $z$ bliska, Jerzy Adamski przedstawia się w następujący sposób: „Mam teraz sześćdziesiąt lat, a połowę mego życia wypełnił teatr. Najpierw, za studenckich czasów, studiowałem to, co da się nazwać teatralną kulturą europejską, bo nie tylko dramat, lecz i recepcję sceniczną. Potem przez długie lata prowadziłem wykłady $z$ historii literatury dla reżyserów i aktorów, próbując przystosować tę bogatą materię do praktycznych potrzeb artystów teatru. Tak wszedłszy w kontakt ze środowiskiem aktorsko-reżyserskim, nie dziwota, że wszedłem i w teatr; nastąpiły lata współpracy z reżyserami, aktorami, dyrektorami $\mathrm{w}$ przygotowywaniu przedstawien, planów repertuarowych, pomysłów inscenizacyjnych" (Adamski 1985: 5).

Wspomniana współpraca zaowocowała zarówno scenicznymi adaptacjami (m.in. Przedwiośnia i Dziejów grzechu Stefana Żeromskiego, Kamiennego świata Tadeusza Borowskiego, Eyżek i księżyca Emila Zegadłowicza czy Pana Tadeusza Adama Mickiewicza), jak i przekładami dramaturgii włoskiej i francuskiej na język polski.

1 Obszerne mówienie refleksji Antoine’a Bermana na temat „pozytywnej krytyki przekładu” zostało zawarte w mojej monografii Cztery razy Don Juan. Polskie dwudziestowieczne przekłady dramatu Moliera, Wydawnictwo Naukowe Uniwersytetu Pedagogicznego, Kraków 2014. 
Jerzy Adamski, absolwent filologii romańskiej na Uniwersytecie Warszawskim (gdzie uzyskał następnie tytuł doktora), uprawiał krytykę literacką i teatralną, był wykładowcą na Uniwersytecie Wrocławskim i Uniwersytecie Warszawskim, w latach 1961-1989 wykładał w Państwowej Wyższej Szkole Teatralnej w Warszawie. Jest autorem licznych szkiców i esejów, wydanej pośmiertnie powieści Uciekinier oraz znanego wszystkim romanistom podręcznika Historii literatury francuskiej. Jest także autorem tłumaczeń sztuk Luigiego Pirandella (Giganci z gór, Sześć postaci szuka autora, Arsenał zjaw), Carla Goldoniego (Stuga dwóch panów), Jeana Geneta (Ścisty nadzór), Jeana-Paula Sartrea (Przy drzwiach zamkniętych) oraz Moliera (Świętoszek, Mizantrop). Wszystkie one doczekały się inscenizacji w wielu polskich teatrach dramatycznych.

Niewiele jednak osób wie, że Adamski jest także autorem przekładu Molierowskiego Dom Juana. Tłumaczenie to nigdy nie doczekało się inscenizacji, nigdy też nie zostało opublikowane - istnieje wyłącznie $\mathrm{w}$ formie maszynopisu z odręcznymi poprawkami tłumacza. Adamski dokonał tego przekładu w latach 1990-1991, jest to więc tekst o cztery lata starszy od tłumaczenia Jacka Trznadla i pięć lat wcześniejszy od przekładu Jerzego Radziwiłowicza. Warto jednak zaznaczyć, że wszystkie trzy tłumaczenia powstały w latach 90. XX wieku, okresie niezwykle przychylnym dla przekładów Moliera, a w szczególności Dom Juana. Dramat ten fascynował Adamskiego jako dzieło nietypowe, niepoddające się klasycznym regułom sztuki dramatycznej - dzieło będące kontestacją modelu, który - jak pisał sam autor przekładu - „wywiedziony przez klasycyzm francuski z kultury antycznej i narzucony Europie, zapanował w jej kulturze teatralnej całkowicie, jako rzekomo uniwersalny model teatru" (Adamski 2000: 28). Molier łamał te zasady w myśl idei, że głównym celem jego kreacji artystycznej jest chęć przypodobania się publiczności. Podczas lektury tłumaczenia Adamskiego odnosi się wrażenie, że - podobnie jak Molier - łamie on pewne zasady „translatorskiej poprawności”, by stworzyć tekst, który spodoba się współczesnemu odbiorcy. Mówiąc o translatorskiej poprawności, mam głównie na myśli zasadę poszanowania integralności tekstu. Adamski traktuje oryginał dość dowolnie, łamie rytm zdań oraz na przemian to skraca, to wydłuża (o nieistniejące w oryginale elementy) wypowiedzi bohaterów dramatu; pewne kwestie dopisuje, inne nadmiernie stylizuje. W wyniku tych zabiegów powstał więc tekst daleko odbiegający od oryginału, obfitujący w ślady tłumacza.

Jego pracę można scharakteryzować za pomocą refleksji Rudolfa Pannwitza, który o tłumaczach pisał, że „ze znacznie większą rewerencją odnoszą się do uzusu własnego języka niż do ducha obcego dzieła”, utrwalając „przy- 
godny stan własnego języka, zamiast gwałtownie wprawić go w ruch za sprawą języka obcego" (Niziołek 2014: 42).

Francuski Dom Juan obfituje w zdania długie, czasami bardzo długie, których rytm i melodia są regulowane za pomocą przecinków i średników. Jacek Trznadel we wstępie do swojego tłumaczenia wyjaśniał, że celowo dzielił wypowiedzi bohaterów na mniejsze jednostki, chcąc „udzielić oddechu tasiemcowym zdaniom długich tyrad bohaterów" (Trznadel 1995: 94). Twierdził bowiem, że tak długie zdania brzmiałyby w dzisiejszej polszczyźnie nienaturalnie ${ }^{2}$. Adamski wyraźnie podziela tę opinię. Jego bohaterowie mówią krótkimi frazami, które naruszają oryginalny rytm wypowiedzi, czasami zmieniają także ich sens oraz stają się zdecydowanie odległe od stylu, jakim naznaczył je autor. Tłumacz stara się uwspółcześnić i uprościć tekst dramatu. Zabieg ten jednak niejednokrotnie powoduje zubożenie zarówno semantycznej, jak i stylistycznej warstwy dzieła. Poezja Molierowskiego języka, brzmiąca wyraźnie choćby w przekładzie Radziwiłowicza, w wersji Adamskiego jest mało widoczna. Wypowiedzi bohaterów mają charakter rzeczowy, tłumacz rzadko ucieka się do użycia metafor, tworzy własne zdania jedynie sensem przypominające oryginał, dodaje do tekstu Moliera wymyślone przez siebie frazy ${ }^{3}$ :

Dom Carlos: Oui, mais sans y vouloir entrer; et nous nous voyons obligés, mon frère et moi, à tenir la campagne pour une de ces fâcheuses affaires qui réduisent les gentilshommes à se sacrifier, eux et leur famille, à la sévérité de leur honneur, puisque enfin le plus doux succès en est toujours funeste, et que, si l'on ne quitte pas la vie, on est contraint de quitter le Royaume $[\ldots]^{4}$

Don Karlos: Tak. Ale do samego miasta nie wejdziemy. Mój brat i ja musimy błąkać się po okolicy z powodu pewnej przykrej sprawy honorowej. Jednej z tych, które po prostu zniewalają szlachcica i jego rodzinę, zmuszając do poddania się okrucieństwu naszego kodeksu honorowego. Okrucieństwo zaś polega na tym, że w tych sprawach honorowych zwycięstwo czy wygrana nieodmiennie oznacza śmierć albo wygnanie.

${ }^{2}$ Rok później Radziwiłowicz obali tę tezę, tworząc przekład, który nie tylko w warstwie słownej, lecz także rytmicznej świadczy o pełnym poszanowaniu wartości oryginału. Długie zdania, dzielone przecinkami i średnikami, idealnie odwzorowują teatralną partyturę, jaką stanowi tekst Moliera.

${ }^{3}$ Elementy wytłuszczone to przykłady wyraźnych śladów tłumacza, który dodaje od siebie nieistniejące w oryginale wypowiedzi.

${ }^{4}$ Akt III, scena 3. 
A oto ten sam fragment w przekładzie Jerzego Radziwiłowicza, w którym nie ma ani jednego zbędnego słowa i który znakomicie odwzorowuje kompozycję oryginału:

Don Carlos: Tak, ale nie chcę do niego wchodzić; bo przymuszeni jesteśmy, mój brat i ja, by wyruszyć w pole dla jednej z tych bolesnych spraw, które nam każą siebie i własną rodzinę poświęcić bezwzględnym wymogom honoru, bo nawet najpomyślniejszy ich obrót skutki przynosi żałosne, skoro, jeśli się udało ujść z życiem, trzeba uchodzić z królestwa.

Już na pierwszy rzut oka widać, że przekład Adamskiego jest znacznie dłuższy od przekładu Radziwiłowicza. Mamy tu do czynienia z zabiegiem, który Berman klasyfikuje jako wydłużanie i niszczenie rytmu oryginału (Berman 1999: 61). Dzielenie wypowiedzi bohatera na mniejsze jednostki powoduje konieczność powtarzania - wbrew oryginałowi - pewnych elementów monologu („okrucieństwu/okrucieństwo”, „naszego kodeksu honorowego/w tych sprawach honorowych"), do którego dochodzi niepotrzebne mnożenie synonimów („succès”/ „zwycięstwo czy wygrana”).

Kolejny przykład jeszcze wyraźniej pokazuje ingerencje w tkankę tekstu, jakich dokonuje Adamski w swym przekładzie:

Dom Juan: Je vous avoue, Madame, que je n'ai point le talent de dissimuler, et que je porte un coeur sincère. Je ne vous dirai point que je suis toujours dans les mêmes sentiments pour vous, et que je brûle de vous rejoindre, puisque enfin il est assuré que je ne suis parti que pour vous fuir; non point pour les raisons que vous pouvez vous figurer, mais par un pur motif de conscience, et pour ne croire pas quavec vous davantage je puisse vivre sans péché. Il m’est venu des scrupules, Madame, et j’ai ouvert les yeux de lâme sur ce que je faisais ${ }^{5}$.

Don Juan: Przyznaję, Madame, że kłamać nie umiem. Serce mam szczere. Nie powiem, że moje uczucia się nie zmieniły. Nie powiem, że płonę jak dawniej. Wiadomo, że wyjechałem, aby nie być razem, że uciekłem. Jednak nie dlatego, czego się domyślasz, lecz z powodu wyrzutów sumienia. Życie z tobą jest grzechem. Naszły mnie skrupuły, Madame, zrozumiałem, co robię. (Adamski)

Don Juan: Muszę powiedzieć, pani, że nie posiadam daru udawania i serce we mnie szczere. Nie powiem więc, że żywię dla niej wciąż te same uczucia i płonę chęcią do-

5 Akt I, scena 3. 
łączenia do niej, skoro jedno jest pewne: wyjechałem po to tylko, by od pani uciec; nie z tych powodów, które możesz sobie wyobrażać, ale że tak mi kazało sumienie i ponieważ nie wierzę, że żyjąc z nią dalej, nie będę żył w grzechu. Naszły mnie wątpliwości, pani, i otworzyły się oczy mej duszy na to, co zrobiłem. (Radziwiłowicz)

Porównanie przekładu Adamskiego z tłumaczeniem Radziwiłowicza pozwala dostrzec liczne tendencje deformacyjne, takie jak racjonalizacja, objaśnianie czy zubożenie jakościowe (Berman 1999: 53, 54, 58) wersji tego pierwszego. Adamski dzieli wypowiedź na krótkie, proste zdania, które nadają wypowiedzi Don Juana zupełnie inny niż w oryginale charakter. Kwiecistość monologu bohatera, charakterystyczna dla jego pełnych hipokryzji wywodów („je n'ai point le talent de dissimuler”, „je suis toujours dans les mêmes sentiments", „j'ai ouvert les yeux de l'âme”, przetłumaczone przez Radziwiłowicza na: „nie posiadam daru udawania”, „żywię wciąż te same uczucia”, „otworzyły się oczy mej duszy”) nabiera w wersji Adamskiego cech krótkich, prostych, suchych, pozbawionych metaforyczności komunikatów. Ponadto Adamski stosuje powtórki („nie powiem”, „nie powiem”) i dopowiedzenia („Wiadomo, że wyjechałem, aby nie być razem, że uciekłem”), które niepotrzebnie wydłużają pewne partie tekstu, zmieniając rytm wypowiedzi).

Istnieją także w tłumaczeniu Adamskiego przykłady przypisywania postaciom dramatu bardziej wyrazistego, bardziej dosadnego niż w oryginale stylu wypowiedzi. Bo nawet jeśli Molier różnicuje język swoich bohaterów w zależności od tego, czy rozmawiają z osobami o równym czy wyższym bądź niższym statusie społecznym, to stylizacje te mieszczą się w ramach charakterystyki danej postaci, nie przekraczają pewnych ustalonych przez autora granic. Adamski często te granice przesuwa, hołdując (charakterystycznej także dla wcześniejszych o kilkadziesiąt lat, Boyowskich przekładów Moliera) zasadzie, że wszędzie tam, gdzie istnieje wybór między słabszym lub bardziej dosadnym wyrażeniem, należy posłużyć się tym drugim. I tak na przykład dialog Don Juana z zazdrosnym wieśniakiem przybiera za sprawą tłumacza charakter brutalnej pyskówki, daleko odbiegającej od francuskiego pierwowzoru. Na pełną pogardy kwestię Don Juana „Czego wrzeszczy?” (w oryginale: Ah! Que de bruit! „Ach, co za hałas”) oraz pogróżkę „No to będziesz brał po łbie” (której na próżno szukać w tekście Moliera) Pietrek odpowiada tyradą gęstą od słowa powszechnie uważanego za wulgarne:

Pietrek: O, kurwa, bijesz pan? O, kurwa, bije! I znowu bije, kurwa! I znowu leje, kurwa! Kurwa, wali i tłucze! Za co, kurwa? [...] Żem mu życie, kurwa, podarował! (Adamski) 
Na tym nie kończy się brutalność języka Pietrka. Przypisany mu przez Adamskiego idiolekt, w którym aż roi się od wulgaryzmów („i już nic, kurwa, nie widac”, „wzrok ci się mąci, boś kota wpierdolił”, „Gdyby nie ja, to dupa”, „Że mnie wkurwiasz”, „a on gówno”, „Mam to w dupie”), sprawia, że zamiast poczciwego, wzbudzającego współczucie i sympatię wieśniaka, który został niesprawiedliwie potraktowany przez wielmożnego pana, mamy do czynienia z najgorszego sortu prostakiem, antypatycznym i odpychającym.

Sganarelowi również zdarza się przemawiać w wersji Adamskiego w sposób znacznie bardziej kolokwialny i bardziej skrótowy, niż wynika to z lektury oryginału:

I. Sganarelle: [...] pensez-vous que pour être de qualité, pour avoir une perruque blonde et bien frisée, des plumes à votre chapeau, un habit bien doré, et des rubans couleur de feu [...], pensez-vous, dis-je que vous en soyez plus habile homme, que tout vous soit permis, et qu’on n’ose vous dire vos vérités? ${ }^{6}$

Sganarel: [...] Myślisz, że skoroś szlachcic, skoro na łbie masz perukę blond i fryzowaną, pióro na kapeluszu, kapotę ze złotem i wstążki czerwone [...], to jużeś lepszy, wszystko ci wolno i nikt ci prawdy w oczy nie powie? (Adamski 1990)

II. Sganarelle: Monsieur, quel diable de style prenez-vous là? Ceci est bien pis que le reste et je vous aimerais bien mieux encore comme vous étiez auparavant. J'espérais toujours de votre salut; mais c'est maintenant que j’en désespère; et je crois que le Ciel, qui vous a souffert jusques ici, ne pourra souffrir du tout cette dernière horreur ${ }^{7}$.

Sganarel: Co to ma, u diabła, znaczyć, Monsieur? Jest teraz jeszcze gorzej niż przed tym. Już wolałbym, żeby było jak było. Miałem wówczas przynajmniej nadzieję, że się pan nawróci, ale teraz to już koniec. Niebiosa jakoś pana znosiły dotychczas. Ale obecnego okropieństwa nie zniosą. (Adamski 1990)

Przekład Adamskiego świadczy także o potrzebie „reżyserowania” tekstu. Molier, jak wiadomo, pisał swe sztuki z myślą o jak najszybszym wystawieniu ich na scenie. Jego teksty zawierają zaledwie śladowe ilości didaskaliów, tłumacz zaś nie opiera się pokusie, by je dopisywać, co wydaje się praktyką nader dyskusyjną.

Sam Adamski, podkreślając subiektywny charakter każdego przekładu, o sztuce tłumaczenia pisał w styczniu 1978 roku, co następuje: „Pojawia się

6 Akt I scena 2.

7 Akt V, scena 4. 
naraz (w ciągu krótkiego czasu) wiele tłumaczeń tego samego tekstu, bardzo różnych i dających świadectwo różnych potrzeb i gustów, które tłumaczony oryginał miałby zaspokoić, różnych wyobrażeń i tradycji, z którymi się go wiąże, różnych i odmiennych sposobów rozumienia tłumaczonego dzieła. Często więc mamy do czynienia $\mathrm{z}$ wieloma bardzo do siebie niepodobnymi wersjami (tłumaczeniami) obcego dzieła (oryginału). [...] Od czasów renesansu tylko oryginałowi przysługuje społeczny szacunek najpierw jako dla własności (osobistej autora, narodowej, kulturowej), a potem jako dla pomnika i świadectwa historii. Przysługuje, więc go żywimy. A tłumaczeniu - nie. I słusznie. Bo to dzieło nie tylko innego (niż oryginał) czasu, innych ludzi, innej kultury, innej historii; tłumaczenie to dzieło - cóż tu ukrywać - podrabiane! Oczywiście, tłumaczenie jest zawsze - jak chcą teoretycy - jakimś rodzajem przeróbki, interpretacji, jakimś osobistym widzeniem i słyszeniem oryginału" (Adamski 1985: 124).

Antoine Berman, zwolennik „tłumaczenia literalnego” (podkreślającego znaczenie „litery”, lettre, w odróżnieniu od „łłowa” znamionującego przekład dosłowny) uważał, że przekład, nie będąc ani odtwarzaniem znaczeń tekstu wyjściowego, ani odwołaniem się do ekwiwalencji dynamicznej, powinien stanowić odczytanie i twórcze odtworzenie w innym języku, innej kulturze i dla innych odbiorców tego, co nazywa on "niepowtarzalną grą signifiants" (Niziołek 2014: 42). Znaczy to, że każdy przekład literacki powinien zostać odtworzony z zachowaniem zarówno treści, jak i formy. Trudno jednak odnaleźć oryginalną formę dramatu w przekładzie Jerzego Adamskiego. Jest to bowiem tekst przypominający bardziej adaptację niż tłumaczenie. Jest zgodnie zresztą z przekonaniami tłumacza - rodzajem dzieła podrabianego, którego najbardziej charakterystyczną cechą jest subiektywne podejście do oryginału. Bardzo dyskusyjne wydaje się skracanie tekstu. Podobnie zresztą jak i dzielenie go na mniejsze jednostki; zabieg taki generuje bowiem zazwyczaj konieczność amplifikacji tekstu, ponieważ tłumacz w kolejnym zdaniu musi nawiązać do tego, co zostało powiedziane w zdaniu poprzednim. Oba te zabiegi sprawiają, że zostaje zaburzony rytm dzieła, które - należy o tym zawsze pamiętać - powstało, by zaistnieć na scenie. W przeciwieństwie do innych form literatury, które dają możliwość powolnego przyswajania treści, sztuka teatralna podlega natychmiastowej ewaluacji dokonanej przez publiczność obecną na przedstawieniu. Podczas spektaklu widz musi bardzo szybko i niemal automatycznie przyswajać płynące ze sceny słowa. Nie ma czasu, by zastanawiać się nad tym, co zostało powiedziane. Komunikat musi być więc możliwie klarowny; każda bardziej literacka, metaforyczna czy obfitująca w nadmiar znaczeń fraza stanowi ryzyko niezrozumienia tekstu. Dlatego też 
część tłumaczy oraz teoretyków przekładu skłania się ku opinii, że przekład teatralny, przekład, który adresowany jest bardziej do widza niż czytelnika, powinien być formą adaptacji oryginału. Adamski zdaje się wyznawać pogląd (bliski zresztą takim badaczom jak choćby Georges Mounin, który był zwolennikiem adaptacji jako strategii przekładowej) ${ }^{8}$, że ponad wierność słowom, gramatyce, składni i stylu w tekście dramatu należy zwrócić szczególną uwagę na te elementy, które zdecydowały o sukcesie teatralnym dzieła w jego rodzimym kraju.

\section{Literatura}

Teksty źródłowe:

Molière, 1971, Le Tartuffe. Dom Juan. Le Misanthrope. Editions Gallimard, Paris.

Molier, Don Juan, przeł. Jerzy Adamski, maszynopis ze zbiorów własnych.

Molier, Don Jun albo Kamienna uczta, przeł. Jerzy Radziwiłowicz, maszynopis ze zbiorów własnych.

\section{Literatura przedmiotowa:}

Adamski, J., 1985, Teatr $z$ bliska, Ludowa Spółdzielnia Wydawnicza, Warszawa.

Adamski, J., 2000, Świat jako niespetnienie albo samobójstwo Dom Juana, Wydawnictwo Iskry, Warszawa.

Berman, A., 1995, Pour une critique des traductions: John Donne, Editions du Seuil, Paris.

Berman, A., 1999, La traduction ou la lettre ou lauberge du lointain, Editions du Seuil, Paris.

Mounin, G., 1968, La traduction au théâtre, „Babel” nr 1, s. 7-11.

Niziołek, R., 2014, Cztery razy Don Juan. Polskie dwudziestowieczne przekłady dramatu Moliera, Wydawnictwo Naukowe Uniwersytetu Pedagogicznego, Kraków.

${ }^{8}$ Mounin (1968) jest zdeklarowanym zwolennikiem procesu udomowienia obcego tekstu, zwłaszcza jeśli chodzi o przekład teatralny. Uważa on, że próby zachowania narodowej i kulturowej oryginalności w tekście przekładu wymagają od widza zbyt dużego wysiłku w przyswajaniu sobie obcych kulturowo elementów i na zawsze pozostaną pomysłem awangardowym, przeznaczonym dla bardzo ograniczonego kręgu odbiorców. 


\section{Jerzy Adamski and his unknown translation of molière's Dom Juan}

Summary

Jerzy Adamski - an outstanding literary critic and educator, the author of numerous articles and essays, was also a translator of Italian and French dramas. He translated texts of Carlo Goldoni, Jean Genet, Jean-Paul Sartre, Luigi Pirndello and Molière. Adamski translated Molière's play Dom Juan which was never staged in the theatre. The translation was completed in 1990, and it exists only as a type-written script with the translator's handwritten notes. The purpose of this article is to introduce the translation to a wider audience and to compare it to the translation produced in the same decade, in 1996, by Jerzy Radziwiłowicz. Many examples of Adamski's own interpretations and imprints on his translation are given, as this text endeavours to provide reasons for his choice of translation strategies.

Keywords: Adamski, theatre translation, translator's traces, Berman, literal translation

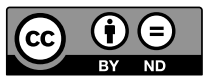

